\title{
Relating Kansas Offenses
}

\author{
Tom Stacy
}

\section{INTRODUCTION}

We live in an era of proliferating criminal offenses. Traditional common law felonies could be counted on two hands. ${ }^{1}$ The Kansas criminal code now contains over nine hundred felonies. ${ }^{2}$ The Kansas Legislature no doubt will continue to add to this already long list. This is understandable and often desirable. Our changing society is constantly becoming more complex; existing offenses have gaps; and democratically elected legislatures have strong incentives to address popularly perceived threats.

One of the more important and vexing legal issues created by this constant offense multiplication concerns their interrelationship. ${ }^{3}$ May a parent who batters a child be convicted of and punished for both aggravated battery and child abuse $?^{4}$ May a person who manufactures methamphetamine be punished both for manufacturing and for possessing necessary ingredients with an intent to manufacture? ${ }^{5}$ May a person who sells cocaine he knows to be talcum powder be convicted of and punished both for theft by deception ${ }^{6}$ and for representing a noncontrolled substance as a controlled substance? ${ }^{7}$ As a consequence of

\footnotetext{
Professor of Law, University of Kansas School of Law. The author would like to thank Melanie Wilson, Jelani Jefferson, and Ed Klumpp for their many helpful comments.

1. See 2 James FitzJames Stephen, A History of the CRiminal Law of England 201-02 (London, MacMillan 1883) (listing common law felonies that existed according to Bracton).

2. Kan. Sentencing Comm'n, Kansas Sentencing Guidelines: Desk Reference MANUAL app. E (2007), available at http://www.kansas.gov/ksc/2007desk.shtml. See generally William J. Stuntz, The Pathological Politics of Criminal Law, 100 MICH. L. REV. 505, 512-19 (2001) (discussing the breadth of state and federal criminal codes).

3. See Paul H. Robinson \& Michael T. Cahill, The Accelerating Degradation of American Criminal Codes, 56 HASTINGs L.J. 633, 635 (2005) (a major problem with modern criminal codes involves "the proliferation of numerous new offenses that duplicate, but may be inconsistent with, prior existing offenses"); Stuntz, supra note 2, at 519 (as a result of offense proliferation, "defendants who commit what is, in ordinary terminology, a single crime can be treated as though they committed many different crimes-and that state of affairs is not the exception, but the rule").

4. See State v. Alderete, 172 P.3d 27 (Kan. 2007).

5. See State v. Schoonover, 133 P.3d 48 (Kan. 2006); see infra Parts II.C, III.B.2.

6. KAN. StAT. ANN. $\$ 21-3701(a)(2)(2007)$.

7. $§ 65-4155$ (2002).
} 
the burgeoning number of offenses, questions such as these pervade the Kansas criminal code.

The answers to these questions have considerable practical and intellectual significance. Allowing multiple convictions can add years to criminal sentences because consecutive sentences are imposed or because the elevated criminal history score lengthens the term of imprisonment for subsequent offenses. Aside from obvious impacts on offenders' loss of liberty and on public protection, this in turn affects prosecutorial charging discretion, judicial sentencing discretion, plea bargaining incentives, and stresses on prison capacity. Offense interrelationships have intellectual significance beyond these practical consequences because the coherence of the criminal code is at stake.

How is the relationship between offenses decided? The legislature of course may specify the intended relationship, but it rarely does so. By default, courts decide. The concepts of the "same" offense, multiplicity, merger, lesser included versus greater offenses, and specific versus general offenses come into play. Courts struggle to give these concepts meaning with resort to generally worded statutes ${ }^{8}$ and a number of competing legal tests. ${ }^{9}$ Yet the guidance furnished by these statutes, concepts, and tests is decidedly imperfect, particularly in the context of an increasingly crowded and complex statutory terrain. The result is confusion and inconsistency. ${ }^{10}$

In light of the attendant difficulties, Kansas law not surprisingly has experienced its share of confusion and controversy. The Kansas Supreme Court of late has become extremely active in addressing the interrelationship of drug offenses. ${ }^{11}$ Its decision in State v. McAdam, ${ }^{12}$ which had the effect of reducing the guideline sentences for methamphetamine manufacture by roughly ten years, caused quite a stir and prompted a swift legislative reaction. In another more recent drug case, State v. Schoonover, ${ }^{13}$ the court candidly acknowledged uncertainty

8. See, e.g., KAN. StAT. ANN. § 21-3107 (2007); Model PENAl CodE § 1.07 (1962).

9. See Schoonover, 133 P.3d at 66-79; Michael H. Hoffheimer, The Rise and Fall of Lesser Included Offenses, 36 RUTGERS L.J. 351, 364-65 (2005) (discussing various approaches to defining lesser included offenses).

10. Cf. Bruce A. Antkowiak, Picking Up the Pieces of the Gordian Knot: Towards a Sensible Merger Methodology, 41 NEW ENG. L. REV. 259, 260 (2007) (describing the law on whether multiple punishments may be imposed for separate offenses as "a mess").

11. State v. Cooper, 179 P.3d 439 (Kan. 2008); State v. Fisher, 154 P.3d 455 (Kan. 2007); State v. Fanning, 135 P.3d 1067 (Kan. 2006); Schoonover, 133 P.3d at 48; State v. Patten, 122 P.3d 350 (Kan. 2005); State v. Campbell, 106 P.3d 1129 (Kan. 2005); State v. Stevens, 101 P.3d 1190 (Kan. 2004); State v. McAdam, 83 P.3d 161 (Kan. 2004).

12. 83 P.3d 161 (Kan. 2004).

13. 133 P.3d 48 (Kan. 2006). 
in its previous cases ${ }^{14}$ and, to restore order, sketched out what is intended to be a comprehensive approach.

This Article examines Kansas case law addressing the interrelationship of drug offenses. The case law is marked not only by uncertainty, but also by inconsistency. ${ }^{15}$ In fact, the only seeming constant has been an approach of legal formalism ${ }^{16}$ that often produces results that make little sense as a matter of statutory interpretation or policy. The Kansas Supreme Court's recent Schoonover decision tries to systematize the formalism. Even if the systematization effort succeeds in reducing uncertainty, it has produced and will continue to produce seriously unsound results. This Article proposes an alternative. Its approach is rooted in realism about the legislative process and sensitivity to the overall aims of the criminal code. In its emphasis on careful attention to context and legislative purpose, this approach bears considerable affinity with the legal process school that grew out of critiques of legal formalism. ${ }^{17}$ The approach urged here, which is

14. Id. at 77 (noting "the doctrinal inconsistency and confusion that abounds in [Kansas] multiplicity cases").

15. The decisions are so convoluted that the court itself has had difficulty keeping them straight. In State v. Fanning, for instance, the court mischaracterized the holding of State v. Patten. 135 P.3d at 1071. Patten held that manufacturing methamphetamine is not multiplicitous with possession of drug paraphernalia with intent to manufacture. $122 \mathrm{P} .3 \mathrm{~d} 350,355-56$. The court in Fanning described Patten as holding that there was no multiplicity for convictions of attempted manufacture (an offense of which the defendant in Patten was not convicted) and possession of drug paraphernalia. 135 P.3d at 1071. Similarly, State v. Campbell withdrew an opinion the court had issued in the case the preceding month. 106 P.3d 1129 (2005). There was no explanation for the withdrawal. The earlier opinion had reached the opposite conclusion, affirming instead of reversing the district court's sentence. State v. Campbell, 101 P.3d 1179 (Kan. 2004), withdrawn, 106 P.3d 1129 (Kan. 2005).

16. The formalist sees the law as a self-contained logical system such that

the major premises in our problem-solving scheme are no more (and no less) than the rules of law; the processes consist exclusively of formal logic; and the correctness of our results is to be verified by an 'internal' analysis, i.e., by asking whether the result coheres with the truths offered by law.

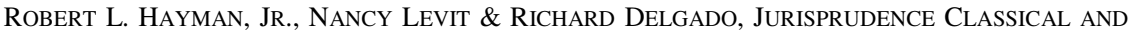
CONTEMPORARY: FROM NATURAL LAW TO POSTMODERNISM 157 (2d ed. 2002); see Justice Oliver W. Holmes, Jr., Supreme Judicial Court of Mass., The Path of the Law, Address at the Dedication of the New Hall of the Boston University School of Law (Jan. 8, 1897), in 10 HARV. L. REV. 457, 465 (1897) (describing formalism as the view that the law "can be worked out like mathematics from some general axioms" such that an erroneous judicial decision is one in which the judges are not "doing their sums right"). Formalism emphasizes rules and, in its most extreme form, denies that judges have discretion in selecting or applying rules, which are instead seen as flowing mechanically from text or precedent. Formalism deemphasizes and, in extreme versions, denies outright the role of statutory or doctrinal purposes in rule selection and application. See generally Guido Calabresi, Essay, Two Functions of Formalism, 67 U. CHI. L. ReV. 479 (2000); Thomas C. Grey, Modern American Legal Thought, 106 YALE L.J. 493, 495-96 (1996) (book review); Frederick Schauer, Formalism, 97 YALE L.J. 509 (1988).

17. The classic statement of legal process theory is found in HenRY M. HART, JR. \& AlBERT 
focused more on harm and culpability than on mechanical tests, promises to improve the court's jurisprudence on the dimensions of both statutory interpretation and criminal justice policy.

\section{ThE CURRENT ForMALISM}

This Part discusses the main features of the Kansas Supreme Court's decisions. The legislature quickly overturned the initial decisions, ${ }^{18}$ which favored the defense by dramatically reducing penalties for those involved in making methamphetamine. Possibly in response, the court's more recent decisions have tended to come out in favor of the prosecution. The common thread has been reliance on a jurisprudential approach fitting the description of legal formalism. For a formalist, the law is an essentially self-contained logical system of rules and doctrines. A judge's role is to reach correct results by a process of a priori deduction from the meaning of legal rules, terms, and concepts. A decision's practical consequences, statutory purposes, policy concerns, the teachings of other disciplines, and social reality more generally are dismissed as extraneous and irrelevant. ${ }^{19}$ This Part's aim is to show that, partly as a consequence of their formalist underpinnings, neither the decisions favoring defendants nor those favoring the State reflect legislative intent or sound policy.

\section{A. Manufacture Versus Distribution: State v. McAdam}

Kansas statutes and sentencing guidelines prescribe markedly different punishments for manufacture and distribution of illegal drugs. Manufacture is a drug severity level 1 felony ${ }^{20}$ for which the sentencing guidelines mandate extremely severe punishment. According to the guidelines, even a first-time offender is to receive a term of imprisonment of over twelve years. ${ }^{21}$ Distribution, by contrast, is

M. Sacks, The Legal Process: Basic Problems in the Making and Application of Law (William N. Eskridge, Jr. \& Philip P. Frickey eds., 1994). Legal process theorists assign statutory and doctrinal purpose a central role in legal interpretation. They tend to see the judicial task as advancing those purposes in case-specific contexts rather than as applying rules that correspond imperfectly to the reasons giving rise to those rules. See Cass R. Sunstein, Justice Scalia's Democratic Formalism, 107 YALE L.J. 529, 539-40 (1997) (book review).

18. The legislature enacted section 65-4159a (Supp. 2007) in response to McAdam, and amended section 65-4150(c) (Supp. 2007) in response to Campbell. KAN. STAT. ANN. §§ 65-4159a, -4150(c) (Supp. 2007).

19. See supra note 16.

20. $§ 65-4159(\mathrm{~b})$.

21. Kan. Sentencing Comm'n, Kansas Sentencing Guidelines: Desk Reference 
generally a drug severity level 3 felony. ${ }^{22}$ The sentencing guidelines put a first-time offender into a "border box," with a presumptive imprisonment of one year and three months. ${ }^{23}$ A recent study concluded that the Kansas guideline sentences for manufacture are harsher ${ }^{24}$ and those for distribution are generally more lenient ${ }^{25}$ than in other selected guideline states.

In State v. McAdam, the Kansas Supreme Court held that the then applicable definition of "manufacture" made it an offense identical to "distribution." When two identical offenses exist, the court declared, the less severe penalty controls. ${ }^{27}$ It accordingly held that those convicted of manufacture could be sentenced only for the less severe offense of distribution.

The court based its conclusion on an entirely formalistic comparison of the offenses. It observed that the distribution offense prohibited "compounding" as well as selling or dispensing a controlled substance. Because the definition of manufacture also encompassed "compounding," and the State had not adequately shown that methamphetamine is made by means other than "compounding," manufacture constituted the same offense as distribution. ${ }^{28}$ The court did not discuss legislative history or intent. It did not discuss the consequences of its decision, which dramatically reduced the length of the sentences available for making methamphetamine by more than ten years. Nor did the court identify any policy goal served by its decision. Instead, it relied entirely on the abstract definition of the offenses found in the statutes' literal text. Consistent with the tenets of legal formalism, the court evidently viewed its role as ensuring the logical coherence of the law regardless of consequences or policy.

McAdam's result is at odds with both legislative intent and criminal justice policy. It is understandable that "compounding" would be

MANUAL app. G, at 1 (2007), available at http://www.kansas.gov/ksc/2007desk/2007\%20Drug\% 20Grid.pdf.

22. $\S \S 65-4161(a),-4163(a)$. The severity level increases for those who committed the offense within 1000 feet of a school, $\S \S 65-4161(\mathrm{~d}),-4163(\mathrm{~b})$, or who distributed certain opiates or stimulants and who have one or more prior convictions for such distribution, § 65-4161(b)-(c).

23. KAN. SENTENCING COMM'N, supra note 21.

24. Don Stemen, Vera Inst. OF Justice, The Kansas Sentencing Guidelines: AN EVAluATION OF PROPORTIONALITY OF SENTENCES 50-51 (2004), available at http://www. accesskansas.org/ksc/documents/Proportionality\%20Study.pdf.

25. Id. at 49. While Kansas guideline sentences for distribution of small amounts of drugs "fall[] in the middle of presumptive sentences for the same offense in other states," sentences for distribution of larger amounts are "lower than the presumptive sentences in most other states." Id.

26. 83 P.3d 161, 167-68 (Kan. 2004).

27. Id. at 168 .

28. Id. at $166-67$. 
included in the distribution offense. Kansas drug statutes are modeled on the Uniform Controlled Substances Act, which establishes a framework for civil regulation of pharmacies as well as creating criminal offenses. ${ }^{29}$ Pharmacies, of course, routinely compound pharmaceuticals. Further, the Uniform Controlled Substances Act treats manufacture and distribution of illicit drugs as part of a single crime. ${ }^{30}$ When the Kansas Legislature created separate crimes for distribution and manufacture, the term "compounding" was evidently carried over into the prolix definitions of both distribution and manufacture. But the use of the term "compounding" in the distribution offense had no effect on the Legislature's intent or criminal justice practices. The Legislature's intent to treat the making of methamphetamine as manufacture could not have been clearer. ${ }^{31}$ The harsh penalty for manufacture was primarily targeted at precisely this conduct. ${ }^{32}$

As for policy, the principal problem with identical offenses is that they give prosecutors unfettered charging discretion. But McAdam did not mention this as a basis for its decision, much less provide any reason to believe that prosecutors were arbitrarily charging the making of methamphetamine as manufacture sometimes and as distribution other times. As far as anyone was or is aware, prosecutors had understood and followed the legislature's design and consistently charged the making of methamphetamine as manufacture.

29. See State v. Luginbill, 574 P.2d 140, 143 (Kan. 1977) (noting that the "National Conference of Commissioners on Uniform State Laws adopted the Uniform Controlled Substances Act" in 1970 and that "[t]wo years later Kansas adopted" the Act). The 1994 version of the Uniform Controlled Substances Act, which is the most recent, is available online at http://www.law.upenn. edu/bll/ulc/fnact99/1990s/ucsa94.htm. For examples of provisions outlining civil regulations of pharmacies, see UNIF. CONTROLLED SuBSTANCES ACT §§ 302-06, 308, 602, 603, 605 (1994); see also, e.g., KAN. STAT. ANN. § 65-4102 (2002).

30. UNIF. CONTROLLED SUBSTANCES ACT § 401 (1994).

31. Section 65-7006(a) of the Kansas Statutes criminalizes the possession of listed ingredients of methamphetamine with an intent to manufacture. KAN. STAT. ANN. § 65-7006(a) (Supp. 2007). When McAdam was decided, section 65-7006(d) made the crime a drug severity level 1 felony. $\S$ 65-7006(d) (2002) (current version at § 65-7006(f) (Supp. 2007)). The legislature obviously wished to punish the actual making of methamphetamine at least at this severity level rather than at drug severity level 3 , which is applicable to the distribution offense.

32. Kansas law enforcement agents, prosecutors, and defense attorneys report that drugs such as LSD, heroin, cocaine, and ecstasy are rarely manufactured in Kansas and that virtually all manufacturing convictions relate to methamphetamine. Illustrative legal database searches confirm this reality. A LEXIS search of "K.S.A. 65-4159 w/6 methamphetamine" yields over sixty cases, most of which involved a defendant who was convicted of manufacturing methamphetamine or a related offense. LEXIS searches of "K.S.A. 65-4159 w/10 cocaine" and "manufactur! w/10 cocaine" yielded no cases in which a defendant had been convicted of manufacturing cocaine. The same was true respecting heroin, LSD, and ecstasy. The legislature, which regularly hears testimony from the Kansas Bureau of Investigation and prosecutors, is undoubtedly aware of the reality that the manufacturing offense almost exclusively targets methamphetamine makers. 
McAdam thus responded to a problem that, in practical terms, did not exist. The imprecise drafting of the manufacturing and distribution offenses evidently had no effect whatever on charging or sentencing practices. One can understand how this imprecision might confound a legal formalist, who views the law as an abstract logical system and the role of the judge as vindicating the law's formal coherence. For the nonformalist, however, the Kansas Supreme Court's remedy is grossly disproportional. Inconsequential legislative-drafting imprecision does not justify the extremely consequential judicial moves of eliminating the intended line between manufacture and distribution and reducing the guideline sentence for making methamphetamine by more than ten years.

It was hardly a surprise that the legislature reacted by quickly overturning McAdam. A few months after the Kansas Supreme Court handed down McAdam, the legislature added section 65-4159a of the Kansas Statutes, reasserting the line it thought it had already drawn between distribution and manufacture. ${ }^{33}$

With some creativity, the Kansas Supreme Court could have fixed the imprecision in a manner consistent with the legislature's intent and without gratuitously reducing sentences. For instance, the court could have interpreted the term "compounding" in harmony with its statutory context. Thus, as used in the distribution offense, "compounding" would take its meaning from the other forms of distribution mentioned in the statute, which all involve the transfer of a drug from one person to another. $^{34}$ The practice of cutting drugs with diluents, which is commonly part of illicit drug sale, would thus constitute "compounding" within the meaning of the distribution offense. The term "compounding," as used in the manufacturing offense, likewise would take its meaning from the other forms of manufacture mentioned therein. All of these forms of manufacture involve bringing a drug into existence rather than transferring the finished product to another person. ${ }^{35}$ It is hardly unusual for the same term to have a different meaning in different

33. Section $65-4159$ a provides that one who is convicted of manufacturing "is guilty of a drug severity level 1 felony" and the "sentence shall not be reduced to violating [the distribution statutes] because prior to this act, such statutes prohibited the identical conduct." $§ 65-4159$ a (Supp. 2007). This section may have only prospective effect. McAdam applies to convictions based on acts occurring before the effective date of section 65-4159a and requires that those convicted of manufacturing be sentenced at drug severity level 3 rather than severity level 1 .

34. See § 65-4161(a) ("[I]t shall be unlawful for any person to sell, offer for sale or have in such person's possession with intent to sell, deliver or distribute; prescribe; administer; deliver; distribute; or dispense ....").

35. See § 65-4101(n) (defining "manufacture" to include, inter alia, "production, preparation, propagation"). 
statutory contexts. ${ }^{36}$ The technique of interpreting one term in keeping with other terms listed in the same provision underlies the familiar maxim of statutory interpretation know as ejusdem generis. ${ }^{37}$ In its formalism, however, the McAdam court did not search for a solution in harmony with the legislature's intent.

McAdam therefore represents legal formalism in its least defensible form. It is law that is divorced from real world context, practical consequences, and legitimate policy concerns. It uses an arid devotion to literal text and abstract legal doctrine to frustrate both clear legislative intent and criminal justice values. As is true of formalist results generally, McAdam's holding cannot be defended on the ground that it was compelled by legal text. Even indulging the assumption that the term "compounding" has exactly the same meaning in the distribution and manufacture offenses, McAdam requires the additional premise that the punishment for identical offenses is controlled by the more lenient penalty. This premise is a judicial confection: it nowhere appears in the code, reflects no constitutional requirement, and, as Part III argues, ${ }^{38}$ should be rejected. As McAdam's aftermath illustrates, formalism can create a relationship between the courts and the legislature that is needlessly uncooperative, if not antagonistic.

\section{B. Paraphernalia Versus Precursors: State v. Campbell}

Separate provisions of the Kansas Statutes address the possession of methamphetamine precursors and the possession of drug paraphernalia. The methamphetamine precursor provision, formerly a drug severity level 1 and now a severity level 2 felony, criminalizes the possession of certain listed chemical ingredients of methamphetamine with an intent to manufacture. ${ }^{39}$ The drug paraphernalia offense, a drug severity level 4 felony, criminalizes possession of paraphernalia with an intent to manufacture or distribute drugs. ${ }^{40}$ In State v. Campbell, the Kansas Supreme Court resolved conflicting decisions of the Kansas Court of Appeals $^{41}$ and held that paraphernalia and precursor offenses are the

36. Cf. State v. Chamberlain, 120 P.3d 319, 326 (Kan. 2005) (noting that the term "conviction" has different meanings in different statutory contexts).

37. "Under the maxim, where enumeration of specific things is followed by a more general word or phrase, such general word or phrase is held to refer to things of the same kind, or things that fall within the classification of the specific terms." State v. Moler, 2 P.3d 773, 775 (Kan. 2000).

38. See infra text accompanying notes 120-22.

39. $\$$ 65-7006(f) (Supp. 2007) (former version at $§ 65-7006(d)(2002)$ ).

40. $\$ 65-4152(a)(3),(c)$ (Supp. 2007).

41. In State v. Frazier, a panel of the Kansas Court of Appeals held the precursor and 
same and therefore a defendant convicted of the precursor offense could be sentenced only for a drug severity level 4 felony. ${ }^{42}$ As in McAdam, the court's formalistic application of the concept of identical offenses thwarted the legislature's clear intent, and did so without furthering any policy goal.

Campbell, which without explanation withdrew and changed the result of an opinion the court had issued in the case a month earlier, ${ }^{43}$ appealed to the literal language of the precursor and paraphernalia offenses. The paraphernalia offense covered not only the specific items of paraphernalia listed in the statute but also " products and materials of any kind' which are intended for use in manufacturing a controlled substance." 44 The phrase "products and materials," the Campbell court reasoned, encompassed the chemical ingredients enumerated in the precursor provision. ${ }^{45}$ Because the two offenses were thus the same, the court held that a defendant convicted of the precursor offense could be sentenced only for paraphernalia, a drug severity level 4 felony. ${ }^{46}$

Campbell reduced the applicable guideline sentence even more dramatically than McAdam. The precursor offense was then graded as a drug severity level 1 felony, which carries a presumptive sentence of 146 months imprisonment for a first-time offender. ${ }^{47}$ The guidelines prefer probation for a first-time offender who commits the paraphernalia offense. ${ }^{48}$ As with McAdam, the legislature responded quickly, enacting legislation to overturn Campbell. ${ }^{49}$

Use of the same offense doctrine was even less defensible in Campbell than in McAdam. As in McAdam, its invocation clearly defied the legislature's intent. Given that the precursors listed in section 65-

paraphernalia offenses to be the same, such that offenders convicted of the precursor offense could be sentenced only at the drug severity level of the paraphernalia offense. 42 P.3d 188, 193 (Kan. Ct. App. 2002). In Campbell itself, the court of appeals had declined to follow Frazier, criticizing that decision for its subversion of legislative intent and mechanical use of the same offense doctrine. State v. Campbell, 78 P.3d 1178, 1185-86 (Kan. Ct. App. 2003), rev'd in part 106 P.3d 1129 (Kan. 2005). The Campbell panel's dissatisfaction with Frazier was premised on earlier criticisms expressed by Judge Knudson in Wilson v. State, 71 P.3d 1180, 1184-85 (Kan. Ct. App. 2003) (Knudson, J., concurring). Campbell, 106 P.3d at 1185-86.

42. 106 P.3d 1129, 1139 (Kan. 2005).

43. State v. Campbell, 101 P.3d 1179 (Kan. 2004), withdrawn, 106 P.3d 1129 (Kan. 2005).

44. Campbell, 106 P.3d at 1139 (citing Kan. StaT. ANN. § 65-4150(c)).

45. Id.

46. Id.

47. KAN. SENTENCING COMM'N, supra note 21.

48. Id.

49. Legislative Research Dep't, Conference Committee Report Brief: Senate BiLl No. 366, 2006 Sess., at 2-366 (Kan. 2006), available at http://www.kslegislature.org/ supplemental/2006/CCRB366.pdf. 
7006(a) of the Kansas Statutes are all ingredients of methamphetamine, the legislature's intent to target methamphetamine was obvious. It was equally obvious that the legislature chose the drug severity level accordingly. But unlike McAdam, judicial creativity was not necessary to effectuate the legislature's intent. To begin with, "paraphernalia" can be interpreted to exclude the chemical ingredients of controlled substances. None of the numerous items specifically listed in the definition of paraphernalia is such an ingredient. ${ }^{50}$ With the exception of cutting agents, which are not active ingredients, ${ }^{51}$ all items mentioned involve physical equipment such as blenders, pipes, and scales. Again, the maxim of statutory construction ejusdem generis holds that a catchall phrase should be limited to items that are like those specifically enumerated. ${ }^{52}$ The general phrase "products and materials," then, easily could be read to include physical equipment and exclude chemical ingredients.

Alternatively, the concept of general versus specific offenses provides a readily available tool by which to accommodate rather than frustrate the legislature's intent. This concept, which the Kansas Supreme Court has relied on before ${ }^{53}$ comes into play when there is a generally framed offense and an offense targeting some subset of the larger area the general offense covers. For example, one offense might criminalize all false statements to governmental officials while another criminalizes false statements made to government officials for purposes of obtaining welfare benefits. It is settled law that the more specific offense controls for purposes of charging, conviction, and punishment.

If "paraphernalia" encompasses chemical ingredients, as Campbell holds, the general versus specific offense concept is clearly applicable. Insofar as the paraphernalia offense prohibits possession of chemical ingredients, it applies generally to ingredients of all controlled substances. The precursor offense, in contrast, specifically addresses the ingredients of one particular controlled substance, namely methamphetamine.

The general versus specific offense doctrine is designed for just this kind of situation. It comes into play when the legislature has determined that some subset of conduct covered by a more general offense deserves more or less punishment. To honor the legislature's determination, the

50. KAN. STAT. ANN. § 65-4150(c) (Supp. 2007)

51. $§ 65-4150(\mathrm{c})(6)$.

52. See State v. Moler, 2 P.3d 773, 775 (Kan. 2000).

53. State v. Williams, 829 P.2d 892, 897 (Kan. 1992); State v. Wilcox, 775 P.2d 177, 178-79 (Kan. 1989). 
offender only may be charged with, convicted of, and sentenced for the specific offense. It is well-known that methamphetamine manufacture creates special dangers. ${ }^{54}$ Its production requires the combination of highly flammable materials and not infrequently results in explosions and fires. Its production also leaves a toxic residue, which can cause injury and entail expensive clean-up. The penalty for the precursor offense was chosen in contemplation of these specific dangers. ${ }^{55}$ It is both natural and in harmony with the legislature's clear intent to view the precursor offense as the offense specific to methamphetamine. On this view, the paraphernalia offense remains available as a general offense for those who possess ingredients intending to make drugs other than methamphetamine such as ecstasy or LSD.

The Campbell court not only neglected to mention the general versus specific offense doctrine, it also employed reasoning that implicitly rejects that doctrine's very existence. The court concluded that the paraphernalia and precursor offenses were identical simply because the paraphernalia offense completely overlapped the precursor offense. ${ }^{56}$ Of course, general and specific offenses also have an overlapping relationship, with the general completely overlapping the specific offense. The neglect and implicit rejection of the general versus specific offense doctrine is unfortunate. That doctrine is a very useful tool for working out the relationship between offenses in a manner that respects legislative intent.

Like McAdam, Campbell is an exercise in legal formalism. The key for the Campbell court was not legislative intent, the real world consequences of its decision, or policy considerations. Instead it was the abstract relationship between the elements of the paraphernalia and precursor offenses. In the court's eyes, this relationship had such a

54. See generally Jean C. O'Connor, Jamie F. Chriqui \& Duane C. McBride, Developing Lasting Legal Solutions to the Dual Epidemics of Methamphetamine Production and Use, 82 N.D. L. REV. 1165, 1170-73 (2006) (describing the special dangers associated with methamphetamine manufacture).

55. The Kansas Legislature has enacted several statutory provisions targeting the special dangers associated with methamphetamine production, thereby indicating its awareness of and desire to punish these dangers specially. Aggravated endangerment of a child explicitly includes exposing children to the dangers of methamphetamine production. § 21-3608a(a)(3)-(4) (2007) ("causing or permitting such child to be in an environment where a person is selling ... [or] manufactur[ing] any methamphetamine" (emphasis added)). Arson includes "accidentally, by means of fire or explosive as a result of manufacturing or attempting to manufacture a controlled substance ... damaging" any dwelling, building, or property. $\$ 21-3718(a)(2)-(3)$. Those who make methamphetamine are civilly liable for the costs of the "actual cleanup or attempted cleanup and for damages for injury to, or both, or destruction of any natural resources caused by chemicals at the site." $§ 65-7011$ (a) (2002).

56. State v. Campbell, 106 P.3d 1129, 1139 (Kan. 2005). 
strong priority that it rendered irrelevant the legislature's clear intent to punish severely those who possess methamphetamine ingredients and justified reducing sentences from more than twelve years imprisonment to presumptive probation. The Campbell court did mention that the existence of identical offenses punished at different levels can give prosecutors unfettered charging discretion. ${ }^{57}$ Consistent with its formalist approach, however, it evidently saw no need to establish this as a real problem rather than a mere academic possibility. In fact, there was no good reason to believe prosecutors had charged methamphetamine precursor possession sometimes as a drug severity level 1 felony and other times as a drug severity level 4 felony.

The parallels with McAdam are striking. In both cases, the Kansas Supreme Court relied upon statutory quirks lacking any discernible practical effect, frustrated the legislature's clear intent, reduced the sentences for makers of methamphetamine dramatically, and neglected to demonstrate that this reduction would meaningfully advance any policy objective. One reasonably might question whether the extremely stiff penalties the legislature has chosen for methamphetamine manufacture are excessive. But whether that policy choice is correct from the standpoint of some impartial and fully informed observer, it is within the bounds of reasonableness. More importantly, it is certainly constitutional. $^{58}$ It is remarkable for courts to invalidate legislative policy choices not because they are unconstitutional but rather because they depart from some ideal of a formally perfect code. In doing so, McAdam and Campbell unnecessarily create an adversarial relationship between the court and the legislature.

\section{Precursors Versus Manufacture: State v. Schoonover}

One who manufactures methamphetamine necessarily possesses essential ingredients with an intent to manufacture. May an offender nonetheless be convicted of and punished for both the manufacture and possessing the precursor ingredients for that same manufacture? In State

57. Id.

58. Tom Stacy, Cleaning Up the Eighth Amendment Mess, 14 WM. \& MARY BiLl RTS. J. 475, 499-500 (2005) ("Only once in the last several decades has the Court invalidated a sentence of imprisonment as grossly disproportionate. During that same period, it has upheld sentences of life imprisonment for three relatively minor property offenses, forty years' imprisonment for possession and distribution of nine ounces of marijuana, mandatory life imprisonment without parole for a first offense of possession of cocaine, and twenty-five years to life under California's 'three-strikes' law for a triggering offense of stealing goods worth approximately $\$ 1,200$.” (footnotes omitted)). 
v. Schoonover, the Kansas Supreme Court held that the answer is yes. ${ }^{59}$

The court began its analysis with an extensive review of federal and Kansas double jeopardy case law limiting punishment imposed for multiple offenses in a single proceeding. ${ }^{60}$ It found that Kansas cases had used two different tests. Some cases had precluded cumulative punishment for offenses arising out of the "same transaction.",61 Other cases had used a "same elements" test, precluding cumulative punishment only when one offense possesses no elements beyond those of the other. ${ }^{62}$ To remedy the confusion and inconsistency resulting from the use of two different tests, the Schoonover court fashioned a two part test. The first part asks whether the offenses arise from the same conduct. $^{63}$ If they do, the second part of the test comes into play, which the court denominated the "same-elements test." ${ }^{\text {" }}$ Multiple convictions and punishment are permissible when "one statute require[s] proof of an element not necessary to prove the other offense."

Applying its two-part test to the facts before it, the Schoonover court affirmed the defendant's convictions for both manufacturing methamphetamine and possessing precursors with an intent to manufacture. The court began by observing that both convictions were based upon the same act, not separate acts of manufacture. ${ }^{66}$ The court therefore turned to the second part of its test, which asks whether the offenses have the same elements. The elements of the manufacturing and precursor offenses, it reasoned, are different because manufacture "requires proof of manufacturing or the ability to manufacture, while possession of ephedrine or pseudoephedrine does not." 67

This result cannot be justified as matter of policy. Methamphetamine cannot be manufactured without possessing the necessary ingredients. When based upon a single act of manufacture, as in Schoonover, possession of necessary ingredients adds to neither the harm nor the culpability already inherent in the manufacture. Additional punishment for precursor possession therefore cannot be defended on the

59. 133 P.3d 48, 81 (Kan. 2006); cf. State v. Patten, 122 P.3d 350, 355 (Kan. 2005) (holding that offenders may be convicted of both methamphetamine manufacture and possession of drug paraphernalia with an intent to manufacture).

60. Schoonover, 133 P.3d at 60-67.

61. Id. at 68-71 (quoting State v. Freeman, 689 P.2d 885, 892 (Kan. 1984)).

62. Id. at $66-67$.

63. Id. at 80 .

64. Id.

65. Id.

66. Id.

67. Id. at 81 . 
ground that the offender deserves such as matter of rational justice. Nor do utilitarian considerations warrant additional punishment.

In addition to authorizing the unwarranted imposition of cumulative punishment, Schoonver's result frustrates other important criminal justice policies. Prosecutors can charge the making of methamphetamine as manufacture, as precursor possession, or both. Depending on the charges, offenders sometimes will be punished for a drug severity level 1 felony, other times for a drug severity level 2 felony, and other times for both level 1 and level 2 felonies. When multiple offenses target separate harms or culpability, the law requires that any increased punishment flowing from multiple convictions be justified by a showing of additional harm or culpability. Schoonover eliminates this important safeguard and so raises the possibility disproportionate and/or disuniform treatment of equally culpable offenders. One can hope that prosecutorial discretion will be exercised wisely so that more culpable manufacturers will face multiple charges and more severe punishment. But the assurance that is present when multiple offenses target separate harms is lacking. Schoonover's result ironically gives prosecutors precisely the kind of unfettered charging discretion the Campbell court sought to exorcise from the law.

Although Schoonover increases the potential punishment for methamphetamine manufacture, it cannot be said that the legislature intended this result. There is no indication that the legislature considered the relationship between the precursor offense and methamphetamine manufacture. Much less is there any reason to believe that a majority of the legislators in both chambers held any particular view concerning their interrelationship.

In fact, there is good reason to believe that if the legislature had considered the matter it would have rejected the Schoonover's court's view. The penalty for methamphetamine manufacture-more than twelve years for a first-time offender-is extremely severe and is harsher than in other sentencing guideline states. ${ }^{68}$ The available evidence indicates that defense attorneys, prosecutors, and judges often regard the guideline punishment as unduly harsh. The available data for 2006, for instance, indicate that downward departures were granted from the guideline sentence applicable to drug manufacturing in approximately eighty-five percent of cases, usually as a result of an agreement between the defense and prosecution. ${ }^{69}$ It is also relevant that state prisons are

68. STEMEN, supra note 24.

69. KAn. SENTENCING COMM'N, FY 2006 AnNUAL RePORT 56, 57 tbl.24 (2007), available at 
rapidly approaching their maximum capacity. ${ }^{70}$ In addition, legislators presumably wish to proportion punishment to harm and culpability, which is a fundamental aim of the criminal code and of criminal law generally. It follows from this principle of proportionality that an offender should not be punished for separate offenses unless those offenses target different harm or culpability. Legislators thus have compelling reasons to reject the imposition of cumulative punishment for an offense targeting no additional harm.

As in McAdam and Campbell, traditional tools of legal interpretation were available to enable the Schoonover court to reach a result compatible with policy and the legislature's presumed intent. Because it is impossible to manufacture methamphetamine without having been in possession of a listed precursor, such possession is an essential, albeit unstated, element of methamphetamine manufacture. Possession of a listed precursor thus fits the definition of a lesser included offense: "[A]11 elements of the lesser crime are identical to some of the elements of the crime charged ...."71 It is settled law that, although an offender may be charged with both a lesser and greater offense, he may not be convicted of and punished for both. ${ }^{72}$

Instead of making use of the concept of lesser included and greater offenses, Schoonover adopted a same-elements test, which flatly contradicts the statutory provision on lesser included and greater offenses. According to Schoonover, multiple convictions and punishment are permissible so long as "one statute require[s] proof of an element not necessary to prove the other offense." "73 Lesser included and greater offenses, of course, satisfy this test: the greater offense by definition requires proof of an element the lesser offense does not. Contrary to Schoonover, section 21-3107 of the Kansas Statutes explicitly provides that a defendant may not be convicted of-and, hence, punished for-both a lesser included and a greater offense. ${ }^{74}$

http://www.accesskansas.org/ksc/2006annual.shtml.

70. The Kansas Department of Corrections 2007 Annual Report reported that, based on the Sentencing Commission's projections, "the department's capacity for male inmates of $8,674 \ldots$ will be exceeded by the end of FY 2008 ...." 2007 KANSAS DEPARTMENT OF CORRECTIONS ANNUAL REPORT 1 (2007), available at http://www.dc.state.ks.us/publications/Revised\%20Annual\% 20Report.pdf.

71. KAN. STAT. ANN. § 21-3107(2)(b) (2007).

72. § 21-3107(2) ("[T]he defendant may be convicted of either the crime charged or a lesser included crime, but not both.").

73. State v. Schoonover, 133 P.3d 48, 80 (Kan. 2006).

74. It is ironic that the court's same-elements test conflicts with section 21-3107. The court relied upon that provision in part as a basis for rejecting the single act of violence test employed in some prior decisions. State v. Schoonover, 133 P.3d 48, 78 (Kan. 2006). The court appears to have confused different aspects of whether offenses are "the same." McAdam and Campbell held offenses 
Like McAdam and Campbell, Schoonover may be criticized for practicing a version of legal formalism that ignores social reality, policy concerns, and legislative intent. It treats as legally irrelevant the reality that methamphetamine cannot be manufactured without possessing the ingredients listed in the precursor offense. ${ }^{75}$ Yet Schoonover made no attempt to explain why the purposes of criminal punishment supported this result. Nor did the court discuss legislative intent. These very same flaws underlie Schoonover's additional holdings that, based on the same act, offenders may be punished for both methamphetamine manufacture and methamphetamine possession ${ }^{76}$ and for both methamphetamine manufacture and possession of drug paraphernalia with an intent to manufacture. ${ }^{77}$

to be identical such that the offender could be punished only under the more lenient penalty provision. For this purpose, Schoonover's same-element test makes sense. It requires that the two offenses have identical elements. Schoonover, however, equates the issue of whether offenses are identical in this sense with the issue of whether multiple punishments may be imposed. A conclusion that an offense is not identical in the sense McAdam and Campbell have in mind does not imply that multiple punishments may be imposed. Consistent with long established law, section 213107 provides that an offender may not be punished both for a greater and a lesser included offense. Of course, lesser included and greater offenses do not have identical elements because the greater offense by definition has one or more elements the lesser does not.

The so-called Blockburger test, which is drawn from the U.S. Supreme Court's decision in Blockburger v. United States, 284 U.S. 299 (1932), is better-suited than the same-elements test to answer whether multiple punishments may be imposed. The Blockburger Court addressed whether the defendant could be validly convicted and punished for two narcotics offenses. It declared: "The applicable rule is that, where the same act or transaction constitutes a violation of two distinct statutory provisions, the test to be applied to determine whether there are two offenses or only one, is whether each provision requires proof of a fact which the other does not." Id. at 304. Under this test, a defendant may not be punished for both a lesser included and a greater offense because the lesser offense does not require proof of a fact which the greater does not. Prior Kansas Supreme Court decisions addressing whether multiple convictions and punishment may be imposed had utilized the Blockburger test. See, e.g., State v. Patten, 122 P.3d 350, 353 (Kan. 2005).

75. Schoonover explicitly rejected the defense's argument that possession of methamphetamine is a lesser included offense of manufacturing methamphetamine. 133 P.3d at 83-84. It is not clear whether the basis of this holding is a mechanical application of the same-elements test, which erroneously permits multiple punishments to be imposed for lesser and greater offenses, see supra note 74 , or a conclusion that it is legally irrelevant that methamphetamine cannot be manufactured without possession of the completed product because this is not formally acknowledged in the stated elements of the manufacturing offense. Particularly given the significance of the consequences for affected individuals, the prison system, and the coherence of the code, it is impossible to understand why this undeniable reality should be treated as legally irrelevant.

76. Schoonover, 133 P.3d at 80-81.

77. Id. at 81 . 


\section{Attempted Manufacture Versus Precursor and Paraphernalia Offenses}

The cases addressing the relationship between attempted manufacture and the precursor and paraphernalia offenses are inconsistent with one another. Schoonover holds that an offender may be convicted of and punished for both manufacture and the precursor offense. $^{78}$ A formalistic application of Schoonover's same-elements test would seem to lead to the same conclusion respecting attempted manufacture and the precursor offense. While both attempted manufacture and the precursor offense require an intent to manufacture, attempted manufacture may be based upon any overt acts, not just precursor possession, and those acts must go beyond mere preparation. ${ }^{79}$ Given that the offense elements are not the same, Schoonover's sameelements test would permit multiple punishment.

In State v. Stevens, however, the Kansas Supreme Court held that the defendant's convictions for attempted manufacture and the precursor offense were multiplicitous. ${ }^{80}$ Instead of the same-elements test applied in Schoonover, the Stevens court applied the test drawn from the United States Supreme Court's decision in Blockburger v. United States. ${ }^{81}$ The Blockburger test permits multiple punishments for separate statutory offenses when "each offense requires proof of an element not necessary to prove the other." 82 The Blockburger test differs from Schoonover's same-elements test. The same-elements test permits multiple punishments if one offense has an element the other does not. Under Blockburger, multiple punishments are permissible only if both offenses have an element the other does not. Under a same-elements test, multiple punishments could be imposed for battery and aggravated battery, because aggravated battery has an element that battery does not. In contrast, Blockburger would preclude multiple punishments because battery has no element that aggravated battery does not.

The Stevens court applied the Blockburger test with reference to the facts adduced at trial rather than the offenses' abstract elements. The

78. Id.

79. KAN. STAT. ANN. § 21-3301(a) (2007) (“An attempt is any overt act toward the perpetration of a crime done by a person who intends to commit such crime but fails in the perpetration thereof or is prevented or intercepted in executing such crime.").

80. 101 P.3d 1190, 1196 (Kan. 2004).

81. 284 U.S. 299 (1932).

82. 101 P.3d at 1195; Blockburger, 284 U.S. at 304. 
prosecution had argued to the jury that the overt act required for attempt liability was established by evidence of the defendant's ephedrine possession. ${ }^{83}$ This same evidence was used to establish the defendant's guilt of the precursor offense. ${ }^{84}$ The Stevens court held that, at least on the particular facts of the case, the offenses' elements were insufficiently distinct and the defendant could not be convicted of and punished for both. ${ }^{85}$ Although Stevens was handed down a couple of years prior to Schoonover's 2006 decision, Schoonover did not address the inconsistency between the same-elements test it adopted and the result in Stevens.

State v. Fanning, ${ }^{86}$ a decision subsequent to both Stevens and Schoonover, addressed the relationship between attempted manufacture and possession of paraphernalia with an intent to manufacture. The issue in Fanning was not whether the defendant could be convicted of and punished for both offenses. The defendant had been convicted only of attempted manufacture, a drug severity level 1 felony. ${ }^{87}$ Instead, at issue was whether attempted manufacture and paraphernalia possession with an intent to manufacture constitute identical offenses such that, consistent with the logic of McAdam and Campbell, offenders guilty of attempted manufacture must be punished at the drug severity level 4 applicable to the paraphernalia offense. ${ }^{88}$ The court held that the offenses were not identical and that the defendant could be punished for a level 1 felony. ${ }^{89}$

The Fanning court based its conclusion on the same-elements test. It acknowledged that previous cases had applied the same-elements test in two different ways. One line of cases, which included Schoonover, looked to offense elements in the abstract. ${ }^{90}$ Other cases applied the test with reference to the facts of the particular case. ${ }^{91}$ The Fanning court sought to reconcile these two lines of cases. It explained that the abstract approach applies when the issue is whether the defendant may be

83. Stevens, 101 P.3d at 1196.

84. Id.

85. Id.

86. 135 P.3d 1067 (Kan. 2006).

87. Id. at 1069.

88. Id. at 1068 .

89. Id. at 1072; cf. State v. Cooper, 179 P.3d 439, 441 (Kan. 2008) (holding that methamphetamine manufacture and possession of paraphernalia with an intent to manufacture are not identical offenses and that offenders convicted of manufacture may be sentenced for such rather than pursuant to the more lenient penalty for the paraphernalia offense).

90. Fanning, 135 P.3d at 1071.

91. Id. 
convicted of two offenses. ${ }^{92}$ The fact-based approach governs when the issue is whether the two offenses are identical such that the defendant may be sentenced only at the less severe offense level. ${ }^{93}$ Finding the issue in Fanning to be of the latter type, the court purported to apply the fact-based approach. Listing the elements of the two offenses, it concluded that the two were not the same because attempted manufacture requires that the manufacture be incomplete, and the paraphernalia offense has no such element. ${ }^{94}$

Several features of Fanning deserve praise. The court reached the correct result. The legislature clearly intends for attempted methamphetamine manufacture to be treated as a drug severity level 1 felony rather than as a level 4 felony that carries presumptive probation for most criminal history scores. ${ }^{95}$ In addition, the Fanning court helpfully acknowledged a division in the court's cases over whether to consider offense elements in the abstract generally or in light of the particular facts adduced at trial. Most helpful of all, the Fanning court distinguished between two separate issues: first, whether offenses are identical such that the more lenient penalty provision governs, and, second, whether multiple convictions and punishments may be imposed. Schoonover conflated these two issues and erroneously adopted the same-elements test for resolution of the latter issue, which contradicts section 21-3107's provisions regarding greater and lesser included offenses. ${ }^{96}$ Fanning unfortunately did not distinguish the two issues for purposes of determining whether to apply a same-elements test or the Blockburger test. Nonetheless, drawing a distinction between issues of offense identity and multiple punishments is a step in the right direction. Whether offenses are identical, general and specific, greater and lesser, or otherwise permit multiple punishment raise different issues and require a different analysis.

Despite its commendable features, Fanning employs analysis that is in some respects seriously confused. First, it is inconsistent with Stevens in both approach and result. Because the issue in Stevens was whether the defendant could be convicted of and punished for two offenses, Fanning would require use of the abstract elements test. Stevens, however, used the fact-based approach by considering the elements in light of the evidence presented at trial. Had Stevens used the abstract

\footnotetext{
92. Id.

93. Id.

94. Id. at 1072

95. See infra notes 134-36 and accompanying text.

96. See supra notes 73-74 and accompanying text.
} 
approach, it would have reached a different result. Considered in light of abstract elements, attempted manufacture and the precursor offense each possess an element the other does not. Attempted manufacture requires overt action going beyond preparation while the precursor offense does not. The precursor offense requires possession of specific ingredients while attempted manufacture does not. It follows from the sameelements test that an offender may be punished for both.

Second, the Fanning court did not use a fact-based approach. It considered the elements of attempted manufacture and the paraphernalia offense in the abstract and did not discuss the evidence that had been adduced at trial to establish those elements. Third, although the Fanning court characterized McAdam and Campbell as using a fact-based approach, neither of those cases focused on the degree of overlap in the evidence adduced at trial to prove two putatively separate offenses.

\section{E. Summary}

The Kansas Supreme Court's decisions regarding relating Kansas offenses are problematic on a number of grounds. Decisions such as McAdam and Campbell subvert the legislature's clear intent. They do so without furthering any identifiable constitutional value or criminal justice policy. A number of the decisions are inconsistent with one another in reasoning or result. The same-elements test, which Schoonover intends as a comprehensive mechanism for resolving issues of both offense identity and multiple punishments, flatly conflicts with section 21-3107's provisions on lesser included and greater offenses. The various problems in large measure are traceable to an approach that bears affinity with the legal formalism in vogue in the late nineteenth and early twentieth centuries. This approach relies on formal offense elements and mechanical tests, and discounts legislative intent, policy considerations, and even undeniable features of social reality as irrelevant.

\section{AWAY FROM FORMALISM}

This Part outlines an alternative method for relating offenses, one which assigns a central role to legislative intent and criminal justice policies as incorporated into the criminal code. It seeks to replace the Kansas Supreme Court's legal formalism with an approach rooted in the legal process school, which emerged in the mid-twentieth century from 
the legal realists' withering critiques of formalism. ${ }^{97}$ The approach outlined in this Part follows the legal process school's emphasis on statutory purpose as an essential guide to legislative intent. ${ }^{98}$ Offense elements remain relevant but are analyzed in a more nuanced fashion and placed within a larger, more particularized framework designed to advance the ultimate purposes of the criminal code. Unlike the framework proffered by the Kansas Supreme Court in Schoonover, the framework outlined here does not use a single test to answer all issues pertaining to offense interrelationships. It instead distinguishes the issue of whether multiple convictions and punishments may be imposed from the separate issue of whether use of a particular offense is required. This framework urges outright rejection of the identical offenses concept invoked in cases such as McAdam and Campbell. After describing the main features of the proposed framework, this Part shows how the framework applies to a number of issues.

\section{A. An Approach for Relating Offenses}

This section begins the task of sketching an alternative approach by identifying considerations that bear on the proper relationship between the judiciary and the legislature. The overriding role of courts in this area, it maintains, is to work in harmony with the legislature, not in opposition to it. The section then discusses how courts might best establish such a collaborative and mutually supportive relationship, particularly in light of the reality that the legislature typically does not consider offense interrelationship issues.

\section{The Judicial Role}

Any approach for relating offenses should be based upon a considered assessment of the role of the courts relative to the legislature. An important starting point is the recognition that the courts' role in this context does not consist of enforcing constitutional constraints against legislative desires. None of the cases discussed in Part II raises the issue of whether an offender may be tried for multiple offenses in separate proceedings, thereby implicating constitutional double jeopardy limitations. They all involve the validity of convictions and punishment

97. See generally Michael Wells, Who's Afraid of Henry Hart?, 14 CONST. COMMENT. 175 (1997) (reviewing Henry M. HART, JR. \& Herbert Wechsler, The Federal Courts and the FEDERAL SYSTEM (1953)).

98. See supra note 17. 
imposed in a single proceeding. The United States Supreme Court has held that, in such circumstances, double jeopardy precludes only the imposition of punishment beyond that which the legislature intends. ${ }^{99}$ In determining whether the legislature intended to permit an offender to be punished for two offenses, the Court has looked to the Blockburger test. ${ }^{100}$ It is true that the Blockburger test also applies when considering whether double jeopardy's ban against being twice put in jeopardy for the "same offense" permits an offender to be tried in separate proceedings for given offenses. ${ }^{101}$ However, when the issue concerns convictions and punishment imposed in a single proceeding, the Blockburger test functions merely as a presumption as to what the legislature intends. If the legislature wishes to permit an offender to be convicted of and punished for offenses that would constitute the "same offense" under Blockburger, constitutional double jeopardy does not stand in the way. In this context, the Constitution thus permits what the legislature intends.

Given that the area is not pervasively structured by constitutional limits, courts should work cooperatively with the legislature to facilitate the results and policies it intends. Courts, of course, have a recognized and accepted role of defying legislative intent to enforce constitutional constraints. More controversially, courts sometimes deliberately overlook actual legislative intent and construct a fictitious intent when the legislature treads perilously close to unconstitutionality or irrationality. When, as here, these roles are not implicated, courts do and should work harmoniously with the legislature. The legislature properly has its eye on the big picture and the resolution of basic policy choices. Courts are tasked with applying general statutory terms and policy choices to highly particularized issues and facts the legislature did not specifically contemplate. In so doing, courts try to support and rationalize the legislature's product by filling in its details in a manner that advances the legislature's basic policy choices. Cases such as McAdam and Campbell, which thwart the Kansas Legislature's clear intent, undermine the harmony between the judicial and legislative branches that ought to characterize this area.

99. Ohio v. Johnson, 467 U.S. 493, 499 (1984); Missouri v. Hunter, 459 U.S. 359, 367 (1983); State v. Schoonover, 133 P.3d 48, 62-65 (Kan. 2006); see Anne Bowen Poulin, Double Jeopardy and Multiple Punishment: Cutting the Gordian Knot, 77 U. Colo. L. REV. 595, 597 (2006); Antkowiak, supra note 10, at 263-64; Hoffheimer, supra note 9, at 400-01.

100. Garrett v. United States, 471 U.S. 773, 779 (1985); Whalen v. United States, 445 U.S. 684, 690-91 (1980).

101. United States v. Dixon, 509 U.S. 688, 688 (1993). 
The courts' supportive role must be structured in light of the reality that the legislature frequently has not considered the relationship between offenses it has enacted. The paraphernalia possession offense, which criminalizes the possession of drug paraphernalia with an intent to distribute or manufacture, is illustrative. This offense is part of a package of offenses found in the Model Drug Paraphernalia Act drafted by the United States Drug Enforcement Administration. ${ }^{102}$ The Act's principal aim, reflected in offenses that criminalize the sale of drug paraphernalia, was to expand the criminal liability of "head shops" and other vendors selling material "which promotes, even glamorizes, the illegal use of drugs by adults and children alike."103 The Act accordingly expands the liability of such vendors beyond principles of accomplice liability and conspiracy by departing from the high level of culpability thereby required. It broadens vendor liability by creating crimes for manufacture and delivery of paraphernalia for a vendor who knows or has reason to know it will be used in connection with illegal drugs. ${ }^{104}$ The Act also creates the paraphernalia possession offense. But, unlike its discussion of the vendor offenses, the Act's commentary does not discuss the function of the paraphernalia offense. Much less does it address that offense's relationship to other drug offenses such as attempted manufacture, attempted distribution, manufacture, or distribution. Nor is there any indication that in adopting the Act, the Kansas Legislature gave any consideration to these offense relationship issues.

Section 21-3107 of the Kansas Statutes, the general statutory provision addressing offense interrelationships, does not provide a comprehensive set of answers. ${ }^{105}$ Subsection (1) addresses when a person may be charged with multiple offenses. It provides that when a person's conduct establishes "more than one crime," he "may be

102. Model Drug Paraphernalia Act (Drug Enforcement Admin. 1979), reprinted in Steven E. Gersten, Drug Paraphernalia: Illustrative of the Need for Federal-State Cooperation in Law Enforcement in an Era of New Federalism, 26 Sw. U. L. REV. 1067 app. A (1997).

103. Id. at prefatory note, reprinted in Gersten, supra note 102, app. A, at 1109.

104. Id. at art. II, § B, reprinted in Gersten, supra note 102, app. A, at 1113. The general rule is that a vendor is not guilty as an accomplice or as a co-conspirator for selling a product he knows will be put to an illegal use. A greater level of culpability, namely an active stake in the success of the criminal venture, is generally required. See United States v. Falcone, 311 U.S. 205, 210-11 (1940); United States v. Peoni, 100 F.2d 401, 403 (2d Cir. 1938). The Act's offenses, by contrast, expand the vendor's liability by diminishing the required culpability so that it encompasses not only knowledge but also negligence.

105. Cf. Michael T. Cahill, Offense Grading and Multiple Liability: New Challenges for a Model Penal Code Second, 1 OHIO. ST. J. CRIM. L. 599, 604 (2004) ("No state has yet enacted a clear and comprehensive statute that sets out in detail an underlying basis or practical method for punishing multiple offenses."). 
prosecuted for each of such crimes." ${ }^{106}$ As for whether a person may be convicted of and punished for multiple offenses, subsection (2) singles out greater and lesser included offenses. It declares that a person may not be convicted of and punished for both a greater and a lesser included offense.

The Kansas Supreme Court implicitly has declined to read section 21-3107 as establishing a comprehensive blueprint for determining relations between offenses. Unlike the Model Penal Code and many state codes, section 21-3107 does not incorporate the concept of general and specific offenses. ${ }^{107}$ Read as establishing a comprehensive set of rules for determining offense interrelatonships, it would remove that concept from Kansas law. Subsection (2) would stand as a lesserincluded-offense exception to an unstated general rule that a person may be convicted of multiple offenses. Given that the provision contains no exception for general and specific offenses, it would follow that a person may be convicted of and punished for both a "general" and "specific" offense. This result is contrary to the accepted rule that a person may be convicted of and punished for only the more specific offense. Furthermore, subsection (1), which permits prosecution for all multiple offenses, would contradict the rule that a person may be charged only with the specific offense and not the general offense. The Kansas Supreme Court has not read section 21-3107 in this fashion. It has treated the general versus specific offense doctrine as part of Kansas law and has relied upon it. ${ }^{108}$ Treating section 21-3107 as providing the sole source of law concerning offense interrelationships would also undermine the concept of identical offenses, upon which McAdam and Campbell rely. Because such offenses are not greater and lesser included

106. In pertinent part, section 21-3107 provides:

(1) When the same conduct of a defendant may establish the commission of more than one crime under the laws of this state, the defendant may be prosecuted for each of such crimes. Each of such crimes may be alleged as a separate count in a single complaint, information or indictment.

(2) Upon prosecution for a crime, the defendant may be convicted of either the crime charged or a lesser included crime, but not both. A lesser included crime is:

(a) A lesser degree of the same crime;

(b) a crime where all elements of the lesser crime are identical to some of the elements of the crime charged;

(c) an attempt to commit the crime charged; or

an attempt to commit a crime defined under subsection (2)(a) or (2)(b).

KAN. STAT. ANN. § 21-3107(1)-(2) (2007).

107. Model Penal Code $\$ 1.07(1)(\mathrm{d})$ (1962); see, e.g., ARK. Code AnN. § 5-1-110(a)(4) (West 1987); Mo. AnN. StAT. \$ 556.041(3) (West 1999).

108. See supra note 53 and accompanying text. 
offenses, it follows from the text of section 21-3107 that an offender may be punished for either or both.

The court is correct in declining to read section 21-3107 as an allencompassing charter for determining offense interrelationships. The general versus specific doctrine is well established. There is no reason to believe that the legislature has even considered removing it from Kansas law, much less made a deliberate decision to do so. Section 21-3107 is better read not as providing a comprehensive set of directions, but rather as codifying some settled rules regarding offense interrelationship. Included in these are the rules that a person may not be punished for both a greater and lesser included offense and that an attempt merges with the completed offense. The Kansas Supreme Court has properly read section 21-3107 as leaving other issues concerning offense interrelationship to the courts.

\section{Implementation of the Legislature's Design}

Courts face a dilemma. Given that the Constitution gives legislatures great leeway, the courts must determine the permissibility of multiple convictions and punishments with reference to legislative intent. But the legislature generally has not addressed the matter. Faced with this conundrum, what should courts do?

The short answer, which is developed more fully below, is that courts should cultivate a common law of offense interrelationships that is designed to facilitate and rationalize the legislature's basic aims. The common law approach is particularly necessary in this area. Offense interrelationships entail just the kind of careful discrimination of issues and attention to case-by-case context that is uniquely suited to the judicial competence. In developing a common law of offense interrelationships, courts do not and should not stand on their own, much less in opposition to the legislature. Instead, they can be guided first by the overall aims of the criminal code, particularly the code's implicit principle of proportionality, and second by offense relationship doctrines. The general versus specific offense doctrine, for instance, is not formally part of the code. It nonetheless can be applied to facilitate the legislature's policy judgments and make the code more coherent. This is precisely the kind of sensitivity to context and statutory purpose that the legal process approach recommends and that a formalist approach inhibits, if not condemns.

Before more specificity is added to this positive vision, an important point must be made about what courts should not do. What they should not do is use an approach that, by design or in effect, mechanically 
minimizes judicial involvement. A minimalist approach makes considerable sense when courts must decide whether to overturn legislative preferences on constitutional grounds. The Blockburger test, which permits multiple punishments for different offenses so long as each contains an element the other does not, exemplifies such an approach. It strikes a balance between separation of powers and federalism values, which argue for giving legislatures leeway, and double jeopardy values, which argue for limiting legislatures in the name of individual freedom. The Blockburger test strikes a balance between these competing constitutional values in a way that maximizes legislative authority over the criminal law and minimizes federal interference with state criminal justice systems. ${ }^{109}$ The test is designed for the situation where the legislature's desires are known and courts must determine whether to set them aside in the name of individual rights guaranteed by the U.S. Constitution. Schoonover's same-elements test, which permits multiple punishments for even greater and lesser included offenses, minimizes the judicial role to an even greater degree.

The Blockburger test, and even more so the same-elements test, reflexively stack the deck in favor of multiple convictions and punishments. Such an indiscriminate, across-the-board presumption cannot be justified as reflecting a considered legislative judgment. This is particularly so in a state such as Kansas, which must balance its budget while striving to keep its taxes low and which is confronted with a prison system nearing capacity. Indeed, the Schoonover court justified adoption of the same-elements test for general purpose use on grounds of certainty and consistency, not legislative intent. ${ }^{110}$

When the legislature's wishes are uncertain and a court's role nonetheless consists in identifying and enforcing those wishes, minimization of judicial oversight prevents courts from performing a useful and needed function. Fixing the relationship between offenses involves nuanced and context-dependent legal issues that legislatures

109. See Poulin, supra note 99, at 603 ("The Blockburger test is not a protective test.").

110. See State v. Schoonover, 133 P.3d 48, 77-78 (Kan. 2006) (listing reasons for adopting the same-elements test); State v. Patten, 122 P.3d 350, 355 (Kan. 2005) (applying the Blockburger test with reference to abstract offense elements rather than trial evidence in each particular case because of this approach's "ease of application and, hence, certainty."). The court did mention legislative intent as one of several reasons for rejecting what it called the "single act of violence/merger doctrine." Schoonover, 133 P.3d at 78 . If one views the only available choices as between the same-elements test and the same act of violence test, then the court did opt for the same-elements test partly based on legislative intent. Of course, these are not the only two choices so that rejection of single act of violence test does not imply support for the same-elements test, particularly respecting all offense interrelationship issues. 
typically have not specifically addressed and that are particularly wellsuited to judicial resolution.

Courts can play a constructive and supportive role relative to the legislature even and perhaps especially when the legislature has not supplied any specific direction. Courts can effectuate legislative intent by using the overarching aims of the criminal code. The Kansas Legislature presumably wishes for ambiguities in the statutes it enacts to be resolved in accordance with the statutes' objectives. It is accordingly a standard technique of legal interpretation for courts to consult statutory purposes. Because the issues at stake involve interpreting the interrelationship of different statutory provisions, courts of necessity must look beyond the four corners of those particular provisions to see how they can and do fit together as part of a coherent code. One fundamental purpose of a criminal code is to prescribe punishment proportionate to both actual or threatened harm and the offender's culpability for it. ${ }^{111}$ This principle of proportioned punishment furnishes an essential guide to courts interpreting the intended interrelationship between offenses.

In considering the implications of this principle, courts must discriminate carefully among the numerous separate issues posed by offense interrelationship and the doctrines designed to address these issues. The issue that McAdam and Campbell address is whether two offenses are "identical" such that an offender may be punished only for the offense carrying the more lenient penalty. Another issue is whether a person may be prosecuted for only one particular offense, an issue addressed by the general versus specific offense doctrine. A final issue concerns whether a person may be prosecuted, convicted, and punished for two overlapping offenses, an issue addressed in part by the lesser included offense doctrine. This necessary separation of issues is implicit in offense relationship doctrines, such as those involving lesser versus greater offenses and general versus specific offenses, and counts as a strong reason supporting their intelligent use.

In outlining its approach in Schoonover, the Kansas Supreme Court did not sufficiently discriminate among distinct issues. Schoonover suggests that one test should apply across the board to all of the issues mentioned in the preceding paragraph. Schoonover identifies that all-

111. This principle is fundamental and pervades the entire code. It explains why intentional murder is treated as a more serious offense than the intentional infliction of great bodily harm even though both offenses require intentional wrongdoing. It explains why intentional murder is treated as a more serious offense than reckless involuntary manslaughter even though both involve the same harm. Innumerable other examples could be given. 
purpose test as the same-elements test, which permits multiple punishments so long as "one statute require[s] proof of an element not necessary to prove the other offense." ${ }^{112}$ In embracing the sameelements test, the Schoonover court perhaps had cases such as McAdam and Campbell in mind, ${ }^{113}$ where the issue was whether two offenses are identical such that the more lenient penalty provision governs. The same-elements test, however, is inadequate for all purposes. The most glaring problem is that it permits convictions and punishments for both a lesser included and a greater offense, contrary to the dictates of section 21-3107 of the Kansas Statutes. ${ }^{114}$ Another problem is that it leaves no room for the doctrine of general versus specific offenses.

Nor can the Blockburger test suffice for all purposes. That test prohibits multiple convictions and punishments unless each offense has an element the other does not. ${ }^{115}$ Of particular relevance to the McAdam and Campbell line of cases, the Blockburger test does not differentiate identical from lesser included offenses. Both "identical" and lesser included offenses flunk this test. Yet, while Blockburger rules out multiple convictions and punishments for both types of offenses, it does not answer whether the more lenient penalty provision governs. McAdam and Campbell hold that when offenses are identical, the lesser penalty provision must be used as the basis for sentencing. Of course, an offender who is guilty of both a lesser included and a greater offense may be punished for the greater offense.

The Blockburger test also does not separate lesser included from specific offenses and is not designed to address or answer the question of whether a particular offense controls. Like lesser included and greater offenses, specific and general offenses may flunk the Blockburger test. Fraud, for instance, has no elements beyond those required by the more specific offense of securities fraud. Under Blockburger, an offender may not be convicted of and punished for both. But when one offense is a more specific version of another, the general versus specific offense doctrine holds that he should be charged with, convicted of, and punished for only the more specific of these two offenses. ${ }^{116} \mathrm{~A}$ legislature, for instance, rationally may conclude that securities fraud

112. State v. Schoonover, 133 P.3d 48, 80 (Kan. 2006).

113. Id. at 82-83 (mentioning McAdam and Campbell in aspects of the opinion other than adoption of the same-elements test).

114. See supra notes 73-74 and accompanying text.

115. See supra notes 81-82 and accompanying text.

116. See supra note 53 and accompanying text. 
deserves a greater penalty than fraud because such an offense tends to have multiple victims and undermine the capital market.

Mechanical elements tests can be useful tools. But they must be used in conjunction with other considerations as part of a larger framework. This framework must carefully discriminate between lesser included and greater offenses, which pertains to the issue of whether an offender may be convicted of and punished for multiple offenses, and general versus specific offenses, which pertains to the issue of whether the legislature intends for a particular offense to exclude others. The analysis of offense elements differs depending on which doctrine is at issue. The concepts of lesser included versus greater offenses and specific versus general offenses are well established and designed to adjust offense interrelationships in a manner consistent with legislative intent. Courts should consider their applicability. Ultimately, of course, offense elements and offense relationship doctrines must be used to effectuate legislative intent.

While deference to legislative intent counsels judicious use of lesser included and general versus specific offense doctrines, it compels rejection of the McAdam/Campbell understanding of identical offenses. McAdam and Campbell hold that when two offenses possess exactly the same elements, sentencing courts must use the more lenient penalty provision even when the offender has been convicted of the other offense. A hard and fast rule that the more lenient penalty controls cannot be squared with the courts' duty to defer to legislative intent. Identical offenses carrying different penalty provisions may exist for at least two reasons. First, the legislature might have been unaware of an identical offense already on the books. If the more recently enacted offense carries a more severe penalty, applying the more lenient penalty provision would unjustifiably subvert the legislature's intent. According to the principle that " $[\mathrm{w}]$ hen a conflict exists, the most recent enactment controls," severe penalty control. ${ }^{118}$

117. State v. Whitesell, 33 P.3d 865, 868 (Kan. Ct. App. 2001).

118. One might argue that the principle of lenity, which resolves ambiguities in criminal statutes in favor of the defendant, necessitates use of the more lenient penalty provision. On this view, there is ambiguity about which penalty provision controls so that lenity requires use of the lesser penalty. In United States v. Batchelder, the U.S. Supreme Court rejected such an argument. 442 U.S. 114 (1979). The defendant had been charged, convicted, and sentenced pursuant to the statute containing the harsher penalty provision. The Court declared: "[T] here is no ambiguity to resolve. Respondent unquestionably violated [the statute, which] unquestionably permits five years' imprisonment for such a violation. That [another statute] provides different penalties for essentially the same conduct is no justification for taking liberties with unequivocal statutory language." Id. at 121-22. 
Second, the legislature may enact identical offenses to increase prosecutorial charging discretion. Courts must honor this legislative intent. Although there are good policy arguments against expanding prosecutorial discretion in this way, the Constitution does not preclude it. In United States v. Batchelder,${ }^{119}$ the U.S. Supreme Court dispatched the argument that the existence of identical offenses carrying different penalties violates the Constitution by giving prosecutors unfettered charging discretion or an improper sentencing role. The Court reasoned: "[T]here is no appreciable difference between the discretion a prosecutor exercises when deciding whether to charge under one of two statutes with different elements and the discretion he exercises when choosing one of two statutes with identical elements." 120 As the Kansas Supreme Court observed in Campbell, the existence of identical offenses with different penalties expands prosecutorial discretion. ${ }^{121}$ In light of the unequivocal holding in Batchelder, however, that fact does not justify courts in declining to follow the unambiguous terms of the statutesubstantive elements and penalty provisions alike-pursuant to which the offender was charged and convicted. The approach urged here thus necessitates rejection of the understanding of identical offenses at work in cases such as McAdam and Campbell.

In summary, courts have a needed and constructive role to play in determining offense interrelationships. Given the absence of pervasive constitutional constraints, courts should base their determinations ultimately on an appraisal of the legislature's intent. It is true that the legislature generally will not have addressed the issue at hand directly. But the reality that legislative intent often cannot be ascertained easily or mechanically does not justify dispensing with the enterprise altogether. It certainly does not warrant formalistic use of mechanical tests and statutory text in a way that subverts any reasonable appraisal of the legislature's design. Courts instead should make use of the powerful tools available for ascertaining legislative intent and rationalizing the code, such as the principle of proportioned punishment and offense relationship doctrines.

\footnotetext{
119. 442 U.S. 114 (1979).

120. Id. at 125. Of course, a prosecutor may not exercise charging discretion based upon constitutionally impermissible criteria such as race or religion. Id. at 125 n.9.

121. State v. Campbell, 106 P.3d 1129, 1137-39 (Kan. 2005).
} 


\section{B. Applications}

This section applies the approach outlined in the preceding section to a number of issues involving the interrelationship of drug offenses. The approach uses reasoning that differs significantly from that employed by the Kansas Supreme Court and, as this section shows, frequently leads to a different result.

\section{McAdam and Campbell}

In McAdam and Campbell, the Kansas Supreme Court invoked the concept of same offenses in a way that reduced the guideline sentence for those involved in making methamphetamine by more than ten years. In so doing, these decisions conflicted with the Kansas Legislature's clearly expressed intent to single this activity out and punish it harshly. The approach here reveals that McAdam and Campbell frustrate legislative intent on a deeper level. That approach asks courts to rely on the fundamental background principle of punishment proportioned to harm and culpability as a guide to legislative intent. Methamphetamine manufacture creates special harms not associated with other drugs. ${ }^{122}$ In dramatically reducing penalties for those who are culpable for creating such harms, McAdam and Campbell undermined the principle of proportioned punishment. The legislature presumably wishes to honor this principle, which structures the entire code.

The approach here counsels courts to use tools of interpretation to advance rather than frustrate legislative wishes. Part II explained how the traditional techniques of interpretation, including the general versus specific offense doctrine, can be employed to accomplish this result. ${ }^{123}$

McAdam and Campbell decline to follow the legislature's intent for reasons that are insufficient. Part II argues that those cases wrongly concluded that the offenses in question were identical. Even assuming that those cases rightly characterized the relationship as one of identity, there was no warrant for holding that the more lenient penalty provision controls both offenses. As the preceding section argued, the McAdam/Campbell conception of identical offenses is unacceptable. Campbell cited the need to avoid "unfettered prosecutorial discretion"124

122. See supra notes $54-55$ and accompanying text.

123. See, e.g., supra text accompanying notes 52-53.

124. Campbell, 106 P.3d at 1139. 
as grounds for requiring use of the lesser penalty. Of course, the existence of such discretion was merely an abstract possibility, not a demonstrated reality. ${ }^{125}$ More importantly, the U.S. Supreme Court's decision in Batchelder makes clear that even the reality of prosecutorial discretion arising from identical offenses does not violate the Constitution. ${ }^{126}$ Absent unconstitutionality, the approach proposed here requires courts to enforce legislative desires that are clearly expressed and implicit in the principle of proportioned punishment.

\section{Manufacture Versus Precursors and Paraphernalia}

In Schoonover, the Kansas Supreme Court held that based on a single act of manufacture a person may be convicted of and punished for both manufacturing methamphetamine and possessing precursors with an intent to manufacture. ${ }^{127}$ In contrast with the situation in Campbell and McAdam, there was no clear and specific evidence of a legislatively intended relationship between these two offenses. By permitting multiple punishments in the absence of additional harm or culpability, Schoonover's holding nonetheless violates the principle of proportioned punishment. That principle is a primary aim of the criminal code, and one which the legislature presumably wishes to further.

The approach outlined in the previous section urges courts to use offense relationship doctrines as a means for implementing the principle of proportioned punishment and, hence, legislative intent. The lesser included offense doctrine relates manufacture and the precursor offense in just this way. This conclusion can be reached through both the Blockburger test and section 21-3107 of the Kansas Statutes, which define a lesser offense as one containing some but not all elements of the greater offense and no elements beyond those of the greater. Because the precursor offense does not require the making of methamphetamine to have actually begun, it does not require all elements of manufacture. The precursor offense, the lesser, requires some of the elements implicitly required by manufacture, the greater. In particular, both offenses require

125. See supra text accompanying note 57.

126. See supra notes 119-20 and accompanying text.

127. An issue not discussed in the text is whether manufacture and the precursor or paraphernalia offenses are identical for purposes of the McAdam and Campbell line of cases. Under the approach proposed here, they are not. This approach rejects the McAdam/Campbell conception of identical offenses. See supra notes 117-21 and accompanying text. In State v. Cooper, the Kansas Supreme Court distinguished rather than repudiated McAdam and Campbell. 179 P.3d 439, 441-42 (Kan. 2008). It nonetheless reached the correct result in holding that manufacture and the paraphernalia offense are not identical. 
possession of ingredients essential to methamphetamine manufacture and an intent to manufacture. It should not matter that manufacture requires possession of necessary ingredients as a matter of practical reality rather than as a formally stated element. To overlook this obvious reality would serve no useful purpose and, in fact, would needlessly frustrate the principle of proportioned punishment and, hence, legislative intent.

Deciding the proper relationship between the paraphernalia offense and manufacture is more difficult. Methamphetamine cannot be manufactured without some types of paraphernalia such as the physical equipment used to "cook" the drug. The analysis in the preceding paragraph would seem to hold respecting paraphernalia fitting this description. However, unlike chemical ingredients, paraphernalia such as physical equipment is not used up in a single act of manufacture and can be used over and over again. Other kinds of paraphernalia are helpful but not necessary to manufacture. For both of these reasons, possession of paraphernalia can involve harms not already inherent in manufacture. Although the significance of these additional harms does not rival that of manufacture, the paraphernalia offense is only a drug severity level 4 felony, not a level 1 felony like manufacture or the precursor offense when Schoonover was decided.

In contrast with manufacture and the precursor offense, multiple convictions and punishment for manufacture and paraphernalia possession accordingly can be reconciled with the principle of proportioned punishment. State v. Patten affirmed the permissibility of multiple convictions and punishment for these offenses through a formalistic application of the Blockburger test. ${ }^{128}$ The approach here endorses the same conclusion through a more extended analysis that consults the principle of proportioned punishment.

Although the paraphernalia offense can involve harm in addition to that already implicit in manufacture, this will not necessarily be so in every case. When it is not, multiple convictions and punishment will conflict with the principle of proportioned punishment. One remedy, which focuses on the sentences, would be to treat the imposition of consecutive rather than concurrent sentences as an abuse of discretion. ${ }^{129}$

128. 122 P.3d 350, 355 (Kan. 2005). The court reasoned: "The crime of manufacture of methamphetamine requires proof of the manufacture of methamphetamine, which is not required in proving possession of drug paraphernalia. The crime of possession of drug paraphernalia requires proof of possession of drug paraphernalia, which is not required in proving manufacture of methamphetamine." Id.

129. This issue would arise very infrequently. The governing statutes and guidelines prohibit consecutive sentences for manufacture and the paraphernalia offense except in very limited circumstances. When the offender has been convicted of both manufacture and the paraphernalia 
Another remedy, which focuses on the convictions, would be to apply the Blockburger test with reference to the facts of each particular case rather than with reference to the offense elements in the abstract. The inquiry would center not on whether the evidence used to establish the paraphernalia offense was also used to establish manufacture, but rather, given the paraphernalia items involved, on whether commission of that offense involved harm in addition to that inherent in manufacture. The Kansas Supreme Court and many other courts have favored the abstract over fact-specific approach to Blockburger on grounds of certainty and ease of application. ${ }^{130}$ Particularly if imposition of consecutive sentences is treated as abuse of discretion in appropriate cases, this is a sensible approach. $^{131}$

offense, the guidelines presume a nonimprisonment sentence for the paraphernalia offense. See KAN. StaT. ANN. § 21-4720(b) (2007) (providing that the paraphernalia offense, as the nonbase crime, be placed in the criminal history I column). A consecutive sentence of imprisonment for the paraphernalia offense may be imposed only if substantial and compelling reasons justify a dispositional departure, $\$ 21-4716$ (a), or if the offender was on probation or parole when the crimes were committed. $\S 21-4603 \mathrm{~d}(\mathrm{f})$.

When the issue does arise, the statutes' literal text appears to give sentencing judges unlimited discretion to impose consecutive sentences. §21-4603d(f) ("[T] he court may sentence the offender to imprisonment for the new conviction, even when the new crime of conviction otherwise presumes a nonprison sentence."); $§ 21-4720$ (b) ("The sentencing judge shall otherwise have discretion to impose concurrent or consecutive sentences in multiple conviction cases."). The suggestion here is that this discretion might be interpreted in light of and as limited by the principle of proportioned punishment that pervades the code.

130. Patten, 122 P.3d at 393. For a discussion of adoption of this approach in other states, see Hoffheimer, supra note 9, at 355, 366-67. In Kansas, a change in the wording of section 21-3107 also bears on the issue of whether courts should consider offense elements in the abstract or in the context of specific facts of the case at hand. In 1998, the legislature amended one portion of that provision's definition of a lesser included offense. The phrase "a crime necessarily proved if the crime charged were proved" was revised to read "a crime where all elements of the lesser crime are identical to some of the elements of the crime charged." Act of May 14, 1998, ch. 185, sec. 1, § 21 3107, 1998 Kan. Sess. Laws 1222. This amendment has been read to preclude use of the factspecific approach. See, e.g., State v. Gilbert, 32 P.3d 713, 717 (Kan. 2001); see also State v. Schoonover, 133 P.3d 48, 73 (Kan. 2006) (noting conflicting precedents). For one discussion of how courts applied the "necessarily proved" phrase in section 21-3107 prior to its amendment, see Jason King, Comment, Simplifying the Issue?: State v. Fike and the Doctrine of Lesser Included Offenses in Kansas, 45 U. KAN L. REV. 1463 (1997). See generally Hoffheimer, supra note 9, at 416-18.

131. The fact-specific approach would make only a marginal contribution to proportioned punishment. Under the suggestion discussed supra in note 129, only concurrent sentences could be imposed in cases where the paraphernalia offense involved no additional harm or culpability. The conviction would remain but merely would affect the sentence for future offenses. In addition, the fact-specific approach would be less efficient. Unlike the abstract approach, it would require appellate review even when the defendant has received concurrent sentences. 
3. Attempted Manufacture and the Precursor and Paraphernalia Offenses

There are several issues concerning the interrelationship between the attempted manufacture and the paraphernalia and precursor offenses. One is whether attempted manufacture and the precursor offense constitute identical offenses in the sense McAdam and Campbell have in mind. Another is whether a person may be punished both for attempted manufacture and the precursor offense based upon the same conduct. These same issues exist respecting attempted manufacture and the paraphernalia offense.

The Kansas Supreme Court has addressed some of these issues. In Stevens it held that, at least on the facts presented, a person may not be convicted of and punished for both attempted manufacture and the precursor offense. ${ }^{132}$ Fanning holds that attempted manufacture and the paraphernalia offense are not the same, so that a person convicted of attempted manufacture is properly sentenced according to the stiffer penalty for that offense. ${ }^{133}$ How would the approach outlined in the preceding section apply to these and the other issues?

Consider the issue of whether these offenses are "identical," such that the more lenient penalty controls. Under the approach proposed here, which rejects the McAdam/Campbell conception of identical offenses, the answer is no. Legislative intent is the touchstone, and a holding that attempted manufacture is identical to the precursor or paraphernalia offense would subvert the penalty deliberately chosen for attempted manufacture. In general, attempted commission of a drug offense yields a sentence six months below the guideline for the completed offense. ${ }^{134}$ The legislature made a considered decision to eliminate this six-month reduction for attempted drug manufacture and punish attempted manufacture and manufacture at the same level. ${ }^{135}$ Punishing attempted manufacture at the lower levels applicable to the paraphernalia and precursor offense would undermine the legislature's explicitly stated decision to treat attempted manufacture as a drug

\footnotetext{
132. See supra Part II.D.

133. Id.

134. KAN. STAT. ANN. § 21-3301(d) (2007).

135. § 65-4159(d) (Supp. 2007) ("The provisions of subsection (d) of K.S.A. 21-3301, and amendments thereto, shall not apply to a violation of attempting to unlawfully manufacture any controlled substance....").
} 
severity level 1 felony. ${ }^{136}$ This decision is clearly constitutional and the approach here requires that courts enforce it. ${ }^{137}$

Now consider whether an offender may be convicted of and punished for both attempted manufacture and the paraphernalia or precursor offenses. The approach outlined here urges use of offense relationship doctrines as a means of implementing the Legislature's intent. One of these, the general versus specific offense doctrine, raises the issue of whether the Legislature intended for persons to be charged with and punished for only one offense and not the other. It did not. The consequences of a holding that the precursor or paraphernalia offenses are specific offenses in relation to the general offense of attempted manufacture would be unacceptable. Such a holding would mean that an offender must be charged with and punished for only the precursor or paraphernalia offenses insofar as attempted manufacture is based upon paraphernalia or precursor possession. This would subvert the legislature's intent to punish attempted manufacture on the same level as completed manufacture.

The principle of proportioned punishment, whose use the approach here recommends as a guide to legislative intent, bolsters the conclusion that the relationship between these offenses is not that of specific and general offenses. There is no reason to conclude that persons who intend to manufacture and whose overt acts have gone beyond preparation have different levels of culpability depending on whether their overt acts are based upon possession of paraphernalia, possession of chemical ingredients, or other acts. Indeed, it seems irrational to conclude that those whose overt acts consist of acquiring needed ingredients or equipment have less culpability than those who have engaged in other overt acts such as planning to acquire such ingredients or equipment. Yet this would be the strange result of treating possession of precursors and possession of paraphernalia as specific offenses to the general offense of attempted manufacture. The precursor and paraphernalia offenses are drug severity level 2 and 4 felonies, respectively, while

136. The precursor offense is currently graded a drug severity level 2 felony, $\S$ 65-7006(f), and the paraphernalia offense as a drug severity level 4 felony. § 65-4152(c).

137. Even if one accepts the identical doctrine, that doctrine can and should be applied consistent with legislative intent. It is possible to interpret attempted manufacture as different from the paraphernalia and precursor offenses, even insofar as attempted manufacture is based upon overt acts of paraphernalia or precursor possession. Whereas attempted manufacture requires that a jury conclude that the person has committed overt acts extending beyond mere preparation, the paraphernalia and precursor offenses treat possession of paraphernalia or precursors as legally sufficient without more. To preserve the level of punishment the legislature clearly intended for attempted manufacture, the approach here requires that attempted manufacture be treated as different from the precursor and paraphernalia offenses. 
attempted manufacture is a drug severity level 1 felony. ${ }^{138}$ The principle of proportioned punishment furnishes a compelling reason to conclude that the legislature would not endorse such a bizarre result.

The remaining issue is whether multiple convictions and punishment are permissible. The inapplicability of the general versus specific doctrine means that prosecutors are not required to use one offense over another. But it does not necessarily imply that prosecutors may obtain convictions and punishment for both. Under the approach proposed here, a court's task is to fashion a result in harmony with legislative intent.

Multiple convictions and punishment for both attempted manufacture, on the one hand, and precursor or paraphernalia possession, on the other, is not supported by the principle of proportioned punishment and, hence, the legislature's presumed intent. Resort to that principle is necessary because the legislature has not addressed this precise issue. Whereas attempted manufacture requires overt action going beyond preparation, the precursor and paraphernalia offenses provide that possession of designated materials is by itself sufficient to establish guilt for those offenses. The culpability and threatened harm associated with attempted manufacture is somewhat greater because the offender potentially is closer to completed manufacture. But this is only marginally so. It will rarely be the case that a jury would conclude that someone is guilty of the paraphernalia or precursor offense but not attempted manufacture. Such a conclusion would require the jury to find that a person who possessed necessary ingredients or paraphernalia such as needed equipment with an intent to manufacture has not gone beyond preparation.

The guideline sentence of ten years and more for attempted manufacture is grossly disproportionate to the marginal additional culpability which theoretically can be (but in practice infrequently will be) associated with attempted manufacture. For this reason, the legislature presumably does not intend for offenders to be convicted of and punished for both attempted manufacture and the precursor or paraphernalia offense.

The best view is that the relationship between attempted manufacture and the precursor and paraphernalia offenses is that between greater and lesser included offenses. Under this conception of the relationship, a person may be charged with both attempted manufacture and the precursor or paraphernalia offense but convicted and punished for only one. When a jury finds that a person has possessed precursors with an

138. $\S \S 65-4152(c),-7006(f), 65-4159(b)$. 
intent to manufacture and, based upon that same conduct, has gone beyond preparation, he is guilty of attempted manufacture. Of course, the elements of the precursor offense are also satisfied. But under the principles governing lesser and greater offenses, the lesser precursor offense merges with the greater so that the person may be convicted and punished only for the greater offense of attempted manufacture.

As compared with permitting multiple convictions and punishment, relating the offenses as greater and lesser offenses is more faithful to the principle of proportioned punishment. Permitting multiple punishments would allow a person to be punished for both a level 1 drug felony and a level 2 or a level 4 felony. For an offender with one prior person felony, the marginal step of moving from precursor or paraphernalia possession to acts a jury finds goes beyond preparation would potentially add 170 months to the offender's sentence. ${ }^{139}$ Under the greater and lesser included offense conception, a person would be punished for a level 1 felony instead of a level 2 or level 4 felony or vice versa. Instead of adding 170 months to the potential sentence, the step from the precursor or paraphernalia possession to attempted manufacture would add 106 and 146 months, respectively. ${ }^{140}$ While still large, this difference is at least more proportionate to the marginally increased harm and culpability associated with attempted manufacture.

In addition, the result can be squared with the elements analysis incorporated into section 21-3107. That provision defines a lesser included offense as one in which "all elements of the lesser crime are identical to some of the elements of the crime charged." 141 Like attempted manufacture, the paraphernalia and precursor offenses require an intent to manufacture and overt action. Attempted manufacture requires the additional element of overt action that goes beyond mere preparation. ${ }^{142}$

\section{CONCLUSION}

The Kansas Supreme Court's decisions relating drug offenses are problematic on a number of levels. Some are inconsistent with one another. Some overlook the applicability of established concepts such as lesser included versus greater offenses and general versus specific offenses. Many decisions contradict the basic criminal law precept that

139. KAn. SENTENCING COMM'N, supra note 21.

140. Id.

141. $§ 21-3107(2)(b)(2007)$.

142. See supra note 79 . 
punishment should be proportioned to harm and culpability. A couple, McAdam and Campbell, run contrary to the Legislature's clear intent. In defying both specific legislative desires and principles of harm and culpability, the decisions pointlessly undermine the collaborative relationship between the legislative and judicial branches that can and should exist in the criminal law context.

These various problems are ultimately traceable to an unacknowledged and undefended reliance on legal formalism revolving around an entirely mechanical use of statutory text, offense elements, and legal tests. Insensitive to legislative intent, criminal justice policy, and social reality, this interpretive approach has led the court to adopt wildly disproportionate remedies for inconsequential drafting flaws and to reduce by more than ten years the harsh sentences the legislature rationally wished to impose on those involved in methamphetamine manufacture. This is legal formalism at its most stubborn and least justifiable.

This Article has outlined a different approach, one that is less mechanical and more inclusive. Offense elements are, of course, relevant. But they are not incorporated into a reductionistic formula such as the Blockbuster test, which Schoonover adopts to answer all offense relationship questions. The precise relevance of offense elements instead should depend on the context and ultimately serve the legislature's intent. The interpretation of legislative intent, in turn, generally requires resort to the principle that criminal punishment be proportioned to harm and culpability. Although this Article's focus has been on drug offenses, the approach it proposes applies to criminal offenses generally. In employing more realistic and constructive methods of interpretation, the Article promises to help rationalize the criminal code, foster a healthier relationship between the legislature and the courts, and distance the Kansas Supreme Court from a largely discredited jurisprudential approach. 